\title{
Mercury contamination in aquatic ecosystems under a changing environment: Implications for the Three Gorges Reservoir
}

\author{
WANG Feiyue $^{1 *} \&$ ZHANG JinZhong ${ }^{2}$ \\ ${ }^{1}$ Center for Earth Observation Science, Department of Environment and Geography, and Department of Chemistry, University of Manitoba, \\ Winnipeg, Manitoba, R3T 2N2, Canada; \\ ${ }^{2}$ Key Laboratory of Eco-Environments in Three Gorges Reservoir Region, Ministry of Education, College of Resources and Environment, \\ Southwest University, Chongqing 400715, China
}

Received May 20, 2012; accepted July 20, 2012; published online October 11, 2012

\begin{abstract}
Mercury is one of the primary contaminants of global concern. As anthropogenic emissions of mercury are gradually placed under control, evidence is emerging that biotic mercury levels in many aquatic ecosystems are increasingly driven by internal biogeochemical processes, especially in ecosystems that have been undergoing dramatic environmental changes. Here we review the unique properties of mercury that are responsible for the exceptional sensitivity of its biogeochemical cycles to changes in climatic, geochemical, biological and ecological processes. We show that, due to rapid climate warming, a shift from sources-driven to processes-driven mercury bioaccumulation is already happening in the Arctic marine ecosystem. We further suggest that such a shift might also be operating in the Three Gorges Reservoir due to changes in these biogeochemical processes induced by the damming. As a result, the effectiveness of mercury emission control is expected to be followed by long delays before ensuing reduction is seen in food-web levels, making it all the more pressing to control and reduce mercury emissions to the reservoir. Long-term monitoring and targeted studies are urgently needed to understand how biotic mercury levels in the reservoir are responding to changes in mercury emissions and in biogeochemical processes.
\end{abstract}

mercury, bioaccumulation, climate change, environmental change, Arctic Ocean, Three Gorges Reservoir, emission control

Citation: Wang F, Zhang J Z. Mercury contamination in aquatic ecosystems under a changing environment: Implications for the Three Gorges Reservoir. Chin Sci Bull, 2013, 58: 141-149, doi: 10.1007/s11434-012-5490-7

Mercury ( $\mathrm{Hg}$ ) is among the first elements discovered and utilized by humans, and its relationship with human society has been a topic of conundrum, controversy, and catastrophe over the past at least 2000 years. Written records of medicinal use of $\mathrm{Hg}$ and cinnabar $(\mathrm{HgS})$ in China can be traced back to at least Shennong Bencao Jing ("Herbal Classic of Shennong", ca. 100 A.D.) which stated that cinnabar could cure almost any disease, nurture the "essence spirit", and, if taken repeatedly, lead to immortality. The latter was fully exploited by the Taoist alchemists in the search of elixir of life. Ancient Egyptians and Greeks used $\mathrm{Hg}$ in skin treatments, which may have prompted the application of $\mathrm{Hg}$ for dealing with syphilis from about the 15th

*Corresponding author (email: wangf@ms.umanitoba.ca) century to the mid-20th century [1].

We now know that $\mathrm{Hg}$ is a non-essential element, and is not required by any known essential biochemical functions of any life form. On the contrary, acute or chronic exposure to $\mathrm{Hg}$ results in adverse biological impacts leading ultimately to death. The medicinal benefits of $\mathrm{Hg}$, if any, are most likely related to its biocidic property. Mercury poisoning was recorded in Paracelsus' work, and neurotoxic effects were noticed in the 19th century with the erythrism symptom [2]. However, it was not until the epidemics in the mid-20th century did the severity of $\mathrm{Hg}$ toxicity start to gain wide-spread attention: first the outbreak of the Minamata Disease in Japan in the 1950s and 1960s and then the grain-related poisoning in Iraq in 1971-1972. In both cases, the toxicity was attributed to the methylated form of $\mathrm{Hg}$, 
methylmercury $\left(\mathrm{CH}_{3} \mathrm{Hg}^{+}\right.$and its various complexes; $\mathrm{MeHg}$ hereafter). The Japanese outbreak was due to human consumption of local seafood that contained elevated concentrations of $\mathrm{MeHg}$ which was formed in the aquatic environment from dumping of industrial $\mathrm{Hg}$ waste [3]. The Iraqi outbreak was due to human consumption of bread prepared from seed wheat treated with MeHg-containing fungicide [4]. It is now well established that $\mathrm{MeHg}$ is one of a few known developmental neurotoxic substances to humans [5].

With the increasing awareness of the toxicity of $\mathrm{Hg}, \mathrm{Hg}$ mining and production for industrial use has been greatly reduced since the 1970s. Anthropogenic emission of $\mathrm{Hg}$ is now dominated by the so-called "by-product" sectors, with fossil fuel combustion for power and heating accounting for nearly 50\% of the total $\mathrm{Hg}$ emission to air [6]. The total global anthropogenic $\mathrm{Hg}$ emissions to air had been stabilized around $1900 \mathrm{t} / \mathrm{year}$ for the period 1990-2005 [6]. Though this number is projected to rise in the next decades [7], international efforts are ramping up to control further $\mathrm{Hg}$ emissions, particularly from the "by-product" sectors. In February 2009, the Governing Council of United Nations Environmental Programme (UNEP) agreed on the need to develop a global, legally binding agreement on $\mathrm{Hg}$ emission. The intergovernmental negotiations are on going, with the goal of reaching a final agreement in 2013.

Despite increasing efforts in emission controls, $\mathrm{Hg}$ remains the primary contaminant of global concern of our time, with elevated $\mathrm{MeHg}$ concentrations frequently exceeding safety thresholds-found in many biota worldwide, especially in aquatic predators such as fish and marine mammals, and even in some of the most remote regions on this planet [6]. This seems count-intuitive: why has source control of $\mathrm{Hg}$ not resulted in alleviation of global $\mathrm{Hg}$ contamination? When, if ever, will we see ecosystems be recovered following source control? These beg for an even more important and timely question: if the ecosystem were not responding, shall we control $\mathrm{Hg}$ emission after all?

Based on a large body of studies on $\mathrm{Hg}$ contamination in the Arctic marine ecosystem, we recently proposed [8] that, to address the above questions, we need to realize and appreciate a new paradigm in driving $\mathrm{Hg}$ contamination: while $\mathrm{Hg}$ contamination in many ecosystems in the past centuries was a direct result of "external" anthropogenic $\mathrm{Hg}$ emissions, it is increasingly driven by "internal" processes that are controlling the transformation and biological uptake of the legacy $\mathrm{Hg}$ that has been stored in the system from the past emissions. We further proposed that such shift in the paradigm is most obvious where these internal processes have been undergoing drastic changes due to climate change [8].

In this paper, we provide an analysis on the sensitivity of $\mathrm{Hg}$ biogeochemistry to changing processes within an aquatic ecosystem. We further argue that, in addition to systems where a shift in the paradigm is driven by climate-induced changes such as in the Arctic Ocean, such a shift from source-driven to process-driven $\mathrm{Hg}$ bioaccumulation could also be prompted by drastic environmental changes due to large-scale engineering operations such as the Three Gorges Reservoir on the Yangtze River. Such a change in the paradigm would have major implications for $\mathrm{Hg}$ contamination and remediation in the region.

\section{Sensitivity of $\mathrm{Hg}$ biogeochemical cycles to environmental change}

Among all the metals, $\mathrm{Hg}$ possesses many unique properties, which make its biogeochemical cycles exceptionally sensitive to climatic (e.g., temperature, light, hydrology), geochemical (e.g., pH, pe, complexing ligands), biological (e.g., feeding behavior of an organism) and ecological (e.g., organic carbon flux, microbial processes, and food web structure and dynamics) processes. Some of these are summarized in Table 1 and highlighted below.

(1) Volatility of $\mathrm{Hg}^{0}$. With a melting point of $-38.8^{\circ} \mathrm{C}$, elemental $\mathrm{Hg}\left(\mathrm{Hg}^{0}\right)$ is the only liquid metal at room temperature and under standard pressure. The high vapor pressure of $\mathrm{Hg}^{0}$ also makes it highly volatile with its volatility greatly dependent on temperature. For instance, the Henry's law constant of $\mathrm{Hg}^{0}$, defined as:

$$
\begin{gathered}
\mathrm{Hg}^{0}(\mathrm{aq})=\mathrm{Hg}^{0}(\mathrm{~g}) ; K_{\mathrm{H}}^{\prime}=\left[\mathrm{Hg}^{0}(\mathrm{~g})\right] /\left[\mathrm{Hg}^{0}(\mathrm{aq})\right] \\
\text { (dimensionless; }\left(\mathrm{ng} / \mathrm{m}^{3} \text { air }\right) /\left(\mathrm{ng} / \mathrm{m}^{3} \text { water }\right)
\end{gathered}
$$

has been shown to increase with temperature following the empirical equation [9]:

\begin{tabular}{|c|c|}
\hline Property & Implications \\
\hline Redox between $\mathrm{Hg}^{0}$ and $\mathrm{Hg}$ (II) & Sensitive to changes in pe and $\mathrm{pH}$; Sensitive to photochemical and microbial processes. \\
\hline $\mathrm{Hg}^{2+}$ ions being one of the softest Lewis acids & Strong affinity to ligands (e.g., reduced sulfides, halogens); Sensitive to changes in organic carbon. \\
\hline $\begin{array}{l}\text { Methylation is primarily microbial, with } \mathrm{MeHg} \\
\text { being the most bioavailable and toxic }\end{array}$ & $\begin{array}{l}\text { Sensitive to changes in organic carbon, nutrients, redox and microbial processes; Direct source } \\
\text { control of } \mathrm{MeHg} \text { difficult. }\end{array}$ \\
\hline $\mathrm{MeHg}$ biomagnifies in the food chain & Sensitive to changes in food web structure and dynamics. \\
\hline
\end{tabular}

Table 1 Unique properties of mercury and implications for its biogeochemistry 


$$
K_{H}^{\prime}=\exp \left(\frac{-2404.3}{T}+6.92\right)
$$

(freshwater or artificial seawater),

where $T$ is in Kelvin. Within the temperature range of $5-30^{\circ} \mathrm{C}$, an increase of $1^{\circ} \mathrm{C}$ (or $1 \mathrm{~K}$ ) in temperature would thus increase the Henry's Law constant of $\mathrm{Hg}^{0}$, and thus its tendency to partition into the air, by $\sim 2.8 \%$. The high volatility of $\mathrm{Hg}^{0}$, its increase with rising temperature, and its generally low reactivity are responsible for the transport of $\mathrm{Hg}^{0}$ in the global atmosphere, in a fashion bearing some similarity to the grasshopper effect of volatile and semivolatile persistent organic pollutants [10], making $\mathrm{Hg}$ a global contaminant.

(2) Redox. Similar to many other trace metals, $\mathrm{Hg}$ is present in the environment in several oxidation states including $\mathrm{Hg}^{0}$ and $\mathrm{Hg}(\mathrm{II})$. Although trace amounts of $\mathrm{Hg}(\mathrm{I})$ may be present in the atmosphere, it is an unstable intermediate and tends to be further oxidized to $\mathrm{Hg}$ (II) or reduced to $\mathrm{Hg}^{0}$ [11]. The redox chemistry of $\mathrm{Hg}$ in the aquatic and terrestrial environments is typically mediated by microbial processes. Unlike many other trace metals, the redox chemistry of $\mathrm{Hg}$ in the atmosphere and surface environment is highly sensitive to UV radiation. Whereas photoreduction of $\mathrm{Hg}$ (II) to $\mathrm{Hg}^{0}$ readily occurs, photooxidation of $\mathrm{Hg}^{0}$ to $\mathrm{Hg}$ (II) occurs primarily via photolytically produced reactive halogen species (e.g., atomic halogens and halogen oxides), making the $\mathrm{Hg}$ cycling sensitive to reactive halogen hotspots. The best example is over the polar oceans during the spring time when sea ice related activation of bromine in the marine boundary layer, known as bromine explosion events [12], could completely oxidize tropospheric $\mathrm{Hg}^{0}$, resulting in the so-called mercury depletion events (MDEs) [13].

(3) Affinity of $\mathrm{Hg}^{2+}$ ions to ligands. Once oxidized, $\mathrm{Hg}$ (II) readily deposits into the surface environment where it subsequently bioaccumulates. With a highly deformable electron sheath, $\mathrm{Hg}^{2+}$ ions are among the softest Lewis acids [14], and thus tend to form strong covalent bonds with soft Lewis bases such as sulfides, selenides, and chloride. As a result, there is virtually no free $\mathrm{Hg}^{2+}$ ions (or more accurately, the aquo complexes $\left.\mathrm{Hg}\left(\mathrm{H}_{2} \mathrm{O}\right)_{x}{ }^{2+}\right)$ in environmental or biological media. Instead, $\mathrm{Hg}$ (II) speciation is dominated by its complexes with dissolved organic carbon (primarily via its sulfhydral function groups) in freshwaters, with chloride in estuarine and marine waters, with sulfide and thiols in anoxic waters [15], and with thiols and thiol-containing proteins in biological systems [16]. Any changes in the type and concentration of these complexing ligands, therefore, will result in major changes in the speciation and bioavailability of $\mathrm{Hg}$.

(4) Methylation. Inorganic $\mathrm{Hg}$ is toxic, but it is its methylate form, $\mathrm{MeHg}$, that is responsible for the biomagnification and neurotoxicity of $\mathrm{Hg}$. The binding of $\mathrm{Hg}^{2+}$ with a methyl group renders $\mathrm{MeHg}$ both hydrophilic and lipophilic, readily passing through boundaries and accumulating within fatty tissues, making $\mathrm{Hg}$ one of few trace elements that are known to biomagnify along the food chain. When binding with cysteine, the resulting methylmercuric cysteinate can be transported across the blood-brain barrier and placental barrier [17], leading to its developmental neurotoxicity. Although methylation can occur abiotically, most of the $\mathrm{MeHg}$ present in ecosystems is formed in the environment via microbial processes. Several species of sulfate reducing bacteria [18], iron reducing bacteria [19] and methanogens [20] are known to methylate $\mathrm{Hg}$, though other microbes including aerobic ones may also be capable of this conversion [21]. The fact that $\mathrm{MeHg}$, the key chemical species responsible for environmental $\mathrm{Hg}$ problems, is formed in situ in the environment after the deposition of inorganic $\mathrm{Hg}$, instead of directly from anthropogenic emissions, poses a major challenge in controlling its levels in the ecosystem.

(5) Biomagnification. Since $\mathrm{MeHg}$ biomagnifies along the food chain, $\mathrm{Hg}$ concentrations in higher trophic level biota are affected not only by the pool of bioavailable $\mathrm{Hg}$ in the abiotic environment, but also by trophic processes that affect biological uptake of $\mathrm{Hg}$. Such processes could be "bottom-up" or "top-down", including [22]: (i) initial MeHg concentrations entering the biota at the bottom of the food web (bottom-up); (ii) species-specific characteristics such as growth rates, age, size, and $\mathrm{Hg}$ elimination rates that impact bioaccumulation or biodilution (bottom-up); (iii) the food web structure and dynamics that defines the transfer of $\mathrm{Hg}$ among trophic levels and/or between food webs, such as benthic-pelagic coupling (bottom-up); and (iv) predator behavior defining diet and feeding ecology (top-down). Because of biomagnification, $\mathrm{MeHg}$ concentration can increase by up to an order of magnitude or more at each successive trophic level. Hence, any changes in these bottomup or top-down processes would have a major effect on the $\mathrm{Hg}$ levels in an ecosystem, particularly in top predators.

\section{Sources vs processes in driving $\mathrm{Hg}$ contami- nation under a changing environment: Signs from the Arctic Ocean}

It becomes clear from the above discussions that the level of $\mathrm{Hg}$ in an ecosystem is determined not only by the influx (natural or anthropogenic) of $\mathrm{Hg}$ to the system, but also by the processes in the ecosystem that control the transport, speciation, bioavailability and biological uptake of $\mathrm{Hg}$, as shown in Figure 1. Given the strong sensitivity of $\mathrm{Hg}$ biogeochemical cycles to a suite of climatic, geochemical, biological and ecological processes (Table 1), any changes in these processes would have the potential to result in major changes in $\mathrm{Hg}$ biogeochemical cycles and ultimately in $\mathrm{Hg}$ levels in biota.

There is no doubt that the significant increase in $\mathrm{Hg}$ 


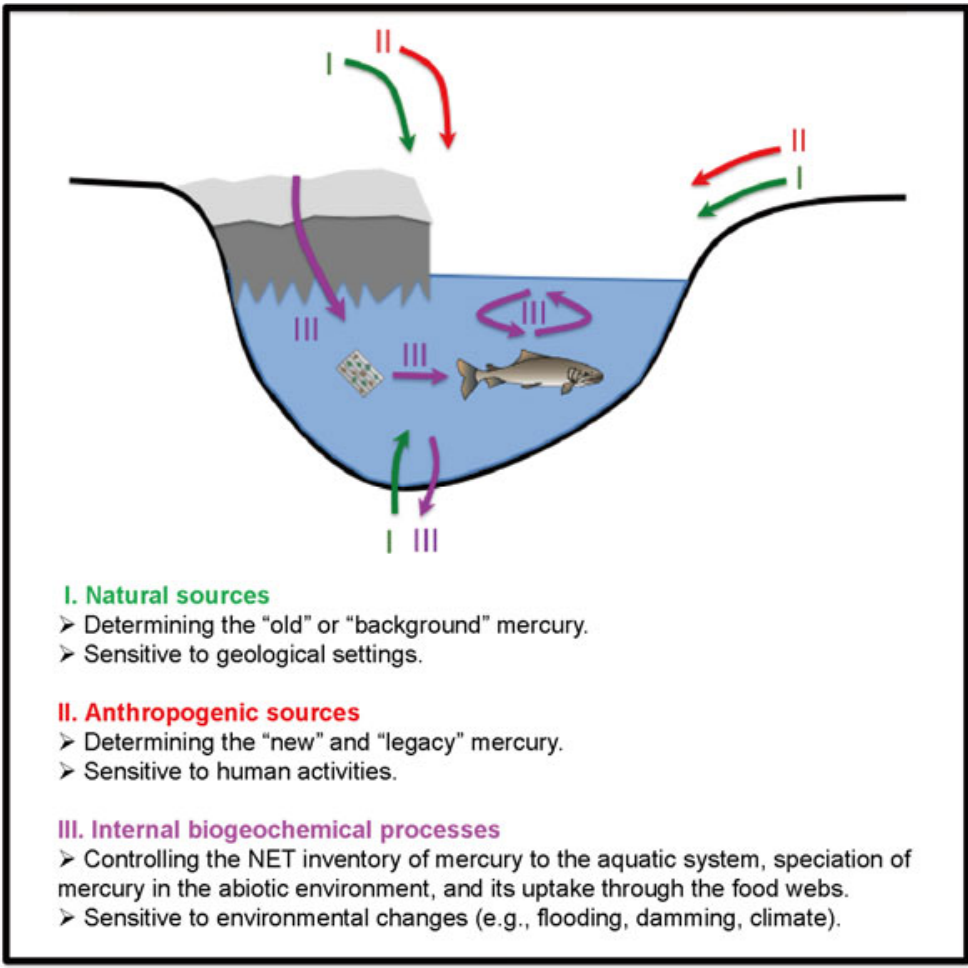

Figure 1 Sources and processes that drive mercury bioaccumulation in aquatic ecosystems.

concentrations in present-day biota in most ecosystems compared to their pre-industrial counterparts is driven primarily by the increase of anthropogenic $\mathrm{Hg}$ emissions. This is supported by the significant increase in anthropogenic $\mathrm{Hg}$ depositional flux recorded in Arctic lake sediment cores and glacier ice cores [6] and in the world's oceans [23]. However, as the accumulated mass of $\mathrm{Hg}$ in a water body becomes large enough relative to the emission-driven loading rate, the internal biogeochemical processes that control the permanent removal (e.g., degradation and burial) or the recycling of the contaminant into the biosphere would increasingly become the determining steps in bioaccumulation.

This shift from sources-driven to processes-driven bioaccumulation of $\mathrm{Hg}$ and other biomagnifying contaminants (e.g., PCBs) was first proposed by Wang et al. [8] and illustrated in Figure 2. Three phases can be distinguished from the figure. During the Holocene and prior to the Anthropocene, the flux of these contaminants was generally low (e.g., $\mathrm{Hg}$ ) or absent (e.g., PCBs), so were their biotic concentrations (Phase I-"Holocene baseline"). At the onset of the Anthropocene, however, industrialization resulted in a sharp increase in the flux of these contaminants to the otherwise "pristine" environment, and biotic concentrations of these contaminants responded rapidly due to increasing exposure and uptake of these chemicals from a small but growing environmental reservoir (Phase II-“External sourcesdriven"). Once a reservoir has accumulated sufficient amount of a chemical, say at a critical influx $\left(F_{\mathrm{c}}\right)$, additional increases in influx become secondary to the recycling of the chemical that has been stored in the environmental reservoir ("legacy" contaminants) accumulated by years of loading. Bioaccumulation then draws predominantly on the "legacy" contaminants, which are operated on by the internal biogeochemical processes (Phase III-“Internal processes-driven"). Throughout all the three phases, biogeochemical cycling (shown as sine-wave "noise" in Figure 2) determines the speciation, bioavailability, and uptake of the contaminant, but it is in the latter phase that these processes emerge to create a variability that is large enough to obscure downturning or up-turning trends, at least at the decadal scale if not longer [8].

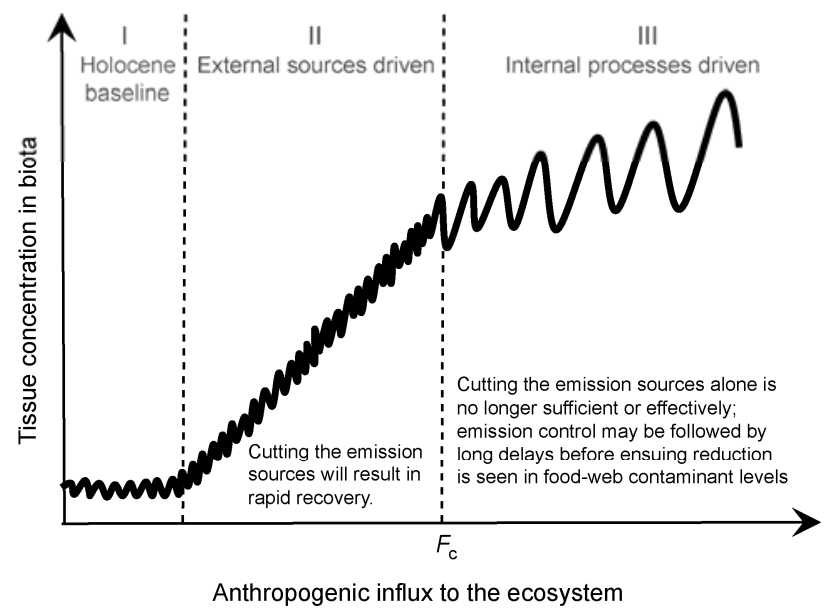

Figure 2 Change of the paradigms in driving bioaccumulation of mercury in the environment and their implications for remediation strategies. Modified from ref. [8]. 
Based primarily on a $\mathrm{Hg}$ mass balance study on the Arctic Ocean [24], we proposed at that time that $\mathrm{Hg}$ bioaccumulation in the Arctic marine ecosystem had reached Phase III in the past 30 years, resulting in "noise" from the processes becoming the main "signal" in the "trend" data for $\mathrm{Hg}$ in Arctic marine animals during the recent decades [8]. This proposal is supported by a recent comprehensive, international assessment of $\mathrm{Hg}$ in the Arctic [6]. While the $\mathrm{Hg}$ concentration in the Arctic troposphere has remained constant or slightly declining since the 1970s [6], a rigorous statistical analysis of all available biotic $\mathrm{Hg}$ time series obtained from the past 30 years or so showed no consistent trend across tissues and species of the entire circumpolar Arctic [6]. Of the 83 time-series analyzed, 13 (16\%) showed a significantly increasing trend, $5(5 \%)$ showed a significantly decreasing trend, 21 (25\%) showed a significant non-linear trend, and the rest 45 (54\%) showed no statistically significant trend [6]. For instance, while $\mathrm{Hg}$ concentrations in polar bear ( $>2$ years) hair from east Greenland (Ittoqqortoormiit; 1984-2008) showed a significantly increasing trend, those from west Greenland (Avanersuaq, 1987-2006) and from Svalbard (1995-2008) showed no significant trend [6]. Similarly, whereas $\mathrm{Hg}$ concentrations in beluga whales in most part of the Canadian Arctic showed an increasing trend, that cannot be said for seals from the same region [6]. The increasing role of internal processes in driving $\mathrm{Hg}$ bioaccumulation in the Arctic is further supported by 8 case studies detailed in the AMAP report [6]: while the signature of atmospheric $\mathrm{Hg}$ deposition was visible in a few case studies, all the case studies supported a role of climatic, biological and ecological processes in determining the biotic $\mathrm{Hg}$ trend in recent decades.

It is not a coincidence that signs of this change in the paradigm would be most profound in the Arctic Ocean, as rapid climate warming has resulted in dramatic changes in many internal biogeochemical and ecological processes that drive $\mathrm{Hg}$ cycling [25]. For instance, the rapid decline in the aerial coverage and thickness of Arctic sea ice and the replacement of multi-year sea ice with first-year ice have the great potential to affect the timing and net deposition of atmospheric $\mathrm{Hg}$ via the occurrence and severity of MDEs and via changes in the timing of ice melting. Rising temperature and changes in organic carbon flux would affect the presence and activity of $\mathrm{Hg}$ methylators thus changing the locality and pool of $\mathrm{MeHg}$ available for biological uptake. Furthermore, any changes in the predator behavior (e.g., habitat use, diet preferences) of an Arctic animal and in the structure and dynamics of Arctic food webs in general would also result in a significance change in the $\mathrm{Hg}$ concentration in the animal [26].

\section{Implications for the Three Gorges Reservoir}

The shift from the sources-driven to processes-driven $\mathrm{Hg}$ bioaccumulation does not necessarily require the $\mathrm{Hg}$ influx to the system reaching a critical value ( $F_{\mathrm{c}}$ in Figure 2$)$. It could also be initiated by dramatic changes in the internal biogeochemical processes. Such dramatic changes can be induced by rapid climate warming as is the case for the aforementioned Arctic Ocean, but they can also be caused by severe natural events such as major flooding, or by large-scale engineering operations. The recently completed Three Gorges Reservoir (TGR) project on the Yangtze River, China, is the largest hydraulic engineering in the world. The reservoir drains though a region that is geologically enriched in $\mathrm{Hg}$ and is among the most $\mathrm{Hg}$ contaminated in the world, due to millennia of mining and smelting of $\mathrm{Hg}$ and other metals (e.g., zinc) and a rapid increase in coalburning power plants [27]. The reservoir region is also home to some 16 million people, as well as source water for all the downstream regions. It is thus important and timely to examine how $\mathrm{Hg}$ cycles in the reservoir respond to both high $\mathrm{Hg}$ emissions from natural and anthropogenic sources and to dramatic changes in internal biogeochemical processes due to the damming.

Water and sediment started to be impounded behind the Three Gorges Dam in June 2003 and the construction of the dam was completed in 2008. The water level of the reservoir reached its designed maximum of $175 \mathrm{~m}$ above the sea level (a.s.l.) in October 2010, and it has since been fluctuating between $145 \mathrm{~m}$ a.s.l. in summer and $175 \mathrm{~m}$ a.s.l. in winter [28]. At its maximum water level, the reservoir stretches some $660 \mathrm{~km}$ with a total surface area of $1080 \mathrm{~km}^{2}$. The reservoir floods a total area of $630 \mathrm{~km}^{2}, 350 \mathrm{~km}^{2}$ of which is a seasonally flooded water level fluctuation zone (WLFZ) due to changes in water level [28]. The impoundment of TGR has brought about many environmental concerns including enhanced sedimentation, decreased self-cleaning capacity of the water body, eutrophication, and contamination by chemicals such as $\mathrm{Hg}$ and changes in their cycling in the reservoir ecosystem.

(1) Mercury sources to TGR. No mass balance model has been constructed for $\mathrm{Hg}$ in TGR, though sporadically available $\mathrm{Hg}$ flux data paint a system that has been stressed by $\mathrm{Hg}$ from natural and anthropogenic sources. A good portion of the TGR drainage basin is located in Guizhou Province on a mercuriferous belt that has been mined for $\mathrm{Hg}$ for more than 2000 years. With more than 12 large and super-large $\mathrm{Hg}$ mines, the province is one of the world's largest $\mathrm{Hg}$ production centers and has a total reserve of cinnabar deposits of nearly $80000 \mathrm{t}$ (as metal Hg) [27]. Although all large-scale $\mathrm{Hg}$ mining activities ceased operations by the beginning of the 21th century, artisanal $\mathrm{Hg}$ mining has continued with much less or non-existing measures to reduce $\mathrm{Hg}$ emission. These artisanal $\mathrm{Hg}$ mines, mining and smelting of other metals from $\mathrm{Hg}$-enriched ores, and the reemission of legacy $\mathrm{Hg}$ stored in mine tailings distinguish $\mathrm{Hg}$ dynamics in TGR from many other water bodies in the world, and need to be fully appreciated when addressing the 
$\mathrm{Hg}$ issues in TGR.

As is the same in the global context [6], coal-fired power plants remain the main source of $\mathrm{Hg}$ in the TGR region. A recent study estimated that coal-fired power plants from Chongqing, Sichuan and Guizhou, where the majority of the TGR watershed is located, emit a total of $11 \mathrm{t} /$ year of $\mathrm{Hg}$ to air in 2007 [29]. To put this number in context, the entire Arctic Ocean, which has a surface area about 9000 times greater than TGR, receives a similar amount of atmospheric $\mathrm{Hg}$ (8.4-98 t/year; [24]). Of course, a fraction of the emitted $\mathrm{Hg}^{0}$ from the power plants is carried out to other regions, but a significant fraction, especially those in the form of $\mathrm{Hg}$ (II) (gaseous or particulate), is deposited in the region and ultimately into the reservoir. The high $\mathrm{Hg}$ emission from the power plants is in part due to the elevated $\mathrm{Hg}$ concentrations in the coal used in the region [30,31]; with an average $\mathrm{Hg}$ concentration of $530 \mathrm{ng} / \mathrm{g}$ (ranging from $100-2670 \mathrm{ng} / \mathrm{g}$ ), coal produced from Guizhou has the highest $\mathrm{Hg}$ level in China [31]). As a result, the $\mathrm{Hg}^{0}$ concentration in ambient air in Chongqing is highly elevated with an annual average of $6.7 \mathrm{ng} / \mathrm{m}^{3}$ [32], which doubles that in remote mountainous areas in the region (Mount Gongga in Sichuan $3.9 \mathrm{ng} / \mathrm{m}^{3}$ [33], and Mount Leigong in Guizhou $2.8 \mathrm{ng} / \mathrm{m}^{3}$ [34]), and more than triples the north hemispheric background values of $<2 \mathrm{ng} / \mathrm{m}^{3}$.

A recent study [35] on the metal concentrations in topsoil $(0-20 \mathrm{~cm})$ in the main stretches of the TGR area showed that on average $\mathrm{Hg}$ concentrations in the region (49 \pm 40 $\mathrm{ng} / \mathrm{g}$; mean \pm s.d.) are comparable with the background levels in China (60 $\pm 70 \mathrm{ng} / \mathrm{g}$; [36]); however, $\mathrm{Hg}$ concentrations as high as $490 \mathrm{ng} / \mathrm{g}$ are found in areas that are underlain by sedimentary limestone due to geological enrichment, or are in the vicinity of urban centers due to deposition of atmospheric $\mathrm{Hg}$ [35]. Much higher $\mathrm{Hg}$ concentrations have been reported in surface soils in the upstream Guizhou province, with concentrations up to $790000 \mathrm{ng} / \mathrm{g}$ near $\mathrm{Hg}$ mines [27].

Much less studied are the concentrations and fluxes of $\mathrm{Hg}$ in industrial wastewater, domestic sewage and solid waste, as well as the losses of $\mathrm{Hg}$ from the system (e.g., sedimentation).

(2) Mercury concentrations in TGR before and after the impoundment. Comparison of $\mathrm{Hg}$ concentrations in abiotic and biotic compartments of TGR before and after the impoundment in 2003 is difficult due to a lack of systematic and holistic studies before and after, and due to inconsistent sampling and analytical methods used in different studies. Table 2 and Figure 3 summarize results from a few published studies. Cautions need to be exercised when making any definitive statements; nevertheless, they do provide a first glimpse at what might have been happening since the impoundment. For instance, in most cases the $\mathrm{Hg}$ concentrations in the river water and sediment/soil seem to have increased after the impoundment (Table 2).

A thorough search of the literature showed that $\mathrm{Hg}$ data for fish before and after the impoundment are only available for three species [41-45]: bronze gudgeon (Coreius heterodon), common carp (Cyprinus carpio) and Amur catfish (Silurus asotus). Although the data are not corrected for fish age, the sizes and weights collected in these studies seemed to be comparable. As can be seen from Figure 3, whereas no significant change has been seen for $\mathrm{Hg}$ concentrations in the muscle of common carp and Amur catfish, they have increased considerably in the muscle of bronze gudgeon since the impoundment. Yu et al. [45] further noted that after the impoundment, higher increase was observed in muscle $\mathrm{Hg}$ concentrations in fish species that are at higher trophic levels and inhabit in deeper waters. A recent study

Table 2 Total mercury concentrations in the Three Gorges Reservoir before and after the impoundment

\begin{tabular}{|c|c|c|c|c|}
\hline & \multicolumn{2}{|c|}{ Before impoundment } & \multicolumn{2}{|c|}{ After impoundment } \\
\hline & Concentration & Reference & Concentration & Reference \\
\hline \multicolumn{5}{|c|}{ River water - Total Hg (ng/L) } \\
\hline Low-water period & 18 & {$[37]$} & 68 & [37] \\
\hline High-water period & 43 & [37] & 49 & [37] \\
\hline \multicolumn{5}{|c|}{ River water - Dissolved Hg (ng/L) } \\
\hline \multicolumn{5}{|c|}{ WLFZ soil - Total Hg (ng/g) } \\
\hline Changshou & 46 & {$[39]$} & 57 & {$[40]$} \\
\hline Fuling & 82 & [39] & 53 & [40] \\
\hline Fengdu & 204 & [39] & 52 & [40] \\
\hline Zhongxian & 62 & {$[39]$} & 103 & {$[40]$} \\
\hline Wanzhou & 85 & [39] & 95 & [40] \\
\hline Fengjie & 35 & [39] & 62 & {$[40]$} \\
\hline Wushan & 34 & [39] & 73 & [40] \\
\hline
\end{tabular}




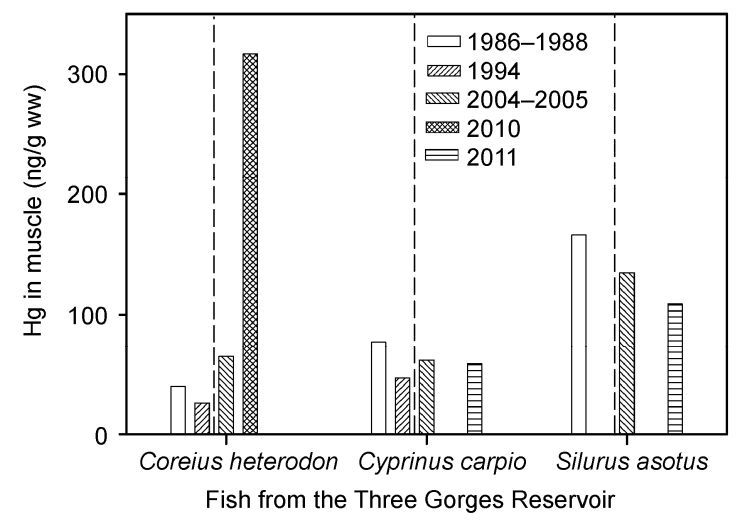

Figure 3 Compilation of available data on $\mathrm{Hg}$ concentrations in fish from the Three Gorges Reservoir before and after the impoundment. Data for 1986-1988 are from [41], 1994 are from [42], 2004-2005 are from [43], 2010 are from [44], and 2011 are from [45]. The dashed line indicates the year (2003) when the reservoir was impounded.

found that the $\mathrm{Hg}$ concentrations in the muscle of bronze gudgeon from Yibin and Banan in the upper reaches of Yangtze Rive and in darkbarbel catfish (Pelteobagrus vachelli) from Yibin have exceeded the safe limit level (300 $\mathrm{ng} / \mathrm{g}$ ww) for human consumption [44]. This is alarming as both are important commercial and edible fish in the region. More studies are needed to verify these concentration ranges and to monitor $\mathrm{Hg}$ concentrations in other fish species from the reservoir.

(3) Impact of damming on processes driving $\mathrm{Hg}$ bioaccumulation in TGR. Reservoirs, particularly recently flooded reservoirs, are known areas of rapid $\mathrm{Hg}$ methylation and thus act as $\mathrm{MeHg}$ sources for bioaccumulation in aquatic food web [46]. This is due to the influx of "fresh" organic carbon at the oxic-anoxic transition zone which promotes the activities of $\mathrm{Hg}$ methylating bacteria $[18,19]$. While this has been extensively demonstrated in North America, it is not unusual to see very low levels of $\mathrm{Hg}$ in freshwater fishes in many reservoirs in China, even in most contaminated regions [47]. This discrepancy can be due to many different processes. Many reservoirs in China have seen extensive past or current aquaculture activities as well as eutrophication, which result in enhanced biodilution of $\mathrm{Hg}$ at the base of food-chain due to algal bloom, enhanced biodilution due to fast growth rate of the fish, and lessened biomagnification due to shortened trophic levels [47]. Sustained stratification may also "protect" the fish by limiting them to feed in oxic and low MeHg-containing epilimnion and thus "disconnecting" their habitat from the high $\mathrm{MeHg}$ zone in the hypolimnion [47]. Alkaline $\mathrm{pH}$ in some of the reservoirs may have also limited the production of $\mathrm{MeHg}$.

Different from small reservoirs such as Baihua Reservoir that have been extensively studied (e.g., [47]), TGR is the second largest reservoir in the world that is formed by damming the Yangtze River, the 4th largest river (in discharge) in the world. As a result, the impact of aquaculture and eutrophication, though occurring in parts of the reservoir, will not likely simplify the food-web structures to the extent seen in smaller reservoirs, at least not in the foreseeable future. Therefore, the biodilution effect will most likely not be as significant as in other reservoirs, making fish, particularly predator fish, potentially more sensitive to $\mathrm{MeHg}$ production in the reservoir.

While damming will have some impact on new sources of $\mathrm{Hg}$ to the reservoir, given that the system has been under high $\mathrm{Hg}$ loading for decades to centuries, the most important effect of damming on $\mathrm{Hg}$ bioaccumulation in the reservoir ecosystem appear to be via changes in internal biogeochemical processes that drive the removal, remobilization and biological uptake of legacy $\mathrm{Hg}$ that has already been accumulated in the system. In other words, the dramatic changes in processes due to human engineering would likely shift $\mathrm{Hg}$ bioaccumulation from being driven by sources (Phase II, Figure 2) to by internal processes (Phase III), similar to the case of the Arctic Ocean where the shift is prompted by climate warming.

Similar to the Arctic Ocean, damming of the Yangtze River will affect both bottom-up and top-down processes in TGR that will ultimately control the $\mathrm{Hg}$ levels in the reservoir ecosystem. Among the most important bottom-up processes that will be affected by the damming is $\mathrm{Hg}$ methylation. The recently flooded farmlands and forests would provide a large influx of "fresh" organic carbon which, when fuelled by $\mathrm{Hg}$ methylators, will produce $\mathrm{MeHg}$ as a byproduct. This is particularly the case for the large area of WLFZ which will be seasonally flooded when the reservoir adjusts the water level, providing the ideal redox conditions for the $\mathrm{Hg}$ methylators. A good fraction of WLFZ was formerly rice paddy fields which are known to produce $\mathrm{MeHg}$ [48].

Other important changes in the processes include: (i) changes in residence time of water and sediment which will affect the critical loading of $\mathrm{Hg}$ in the reservoir; (ii) changes in sedimentation rate which will affect $\mathrm{Hg}$ removal from the water column; (iii) changes in feeding and habitat selection of biota due to the changes in hydrology among others; and (iv) changes in food web structures and dynamics due to eutrophication, aquaculture and invasive species. While some of these processes tend to increase $\mathrm{Hg}$ concentrations in predator fish, others may decrease $\mathrm{Hg}$ bioaccumulation, resulting in greater difficulty in predicting $\mathrm{Hg}$ trend in biota in the reservoir (Table 3).

\section{Conclusions}

While $\mathrm{Hg}$ (and contaminants in general) research and management has so far primarily focused on source reduction, evidence is emerging that the effectiveness of controlling "external" $\mathrm{Hg}$ sources is being increasingly modified by changes in "internal" biogeochemical processes in the aquatic ecosystem. Such shift from sources-driven to 
Table 3 Summary of likely impacts of damming on biota $\mathrm{Hg}$ levels in the Three Gorges Reservoir ${ }^{\text {a) }}$

\begin{tabular}{lcc}
\hline Process & Likely change & $\begin{array}{c}\text { Likely impact } \\
\text { on biotic Hg }\end{array}$ \\
\hline Atmospheric deposition & + & + \\
Evasion & + & - \\
Riverine inputs & + & + \\
Soil erosion & + & + \\
Mercury methylation & + & + \\
Demethylation & \pm & \pm \\
Eutrophication and primary productivity & + & - \\
Scavenging and sedimentation & + & - \\
Food-web structure and dynamics & \pm & \pm \\
\hline
\end{tabular}

a) "+" indicates increases in process rates and impact of biotic $\mathrm{Hg}$ levels; "-" indicates decreases in rates and impacts; " \pm " indicates no or unknown change.

processes-driven $\mathrm{Hg}$ bioaccumulation has been demonstrated in the Arctic marine ecosystem that has been undergoing dramatic changes due to rapid climate warming.

Located in a region that is geologically enriched in $\mathrm{Hg}$, the TGR area has also received large amounts of anthropogenic $\mathrm{Hg}$ from coal-burning power plants, mining and smelting industries and other activities. Following impoundment in 2003, major changes have already been occurring in the reservoir, many of which will have direct influence on the cycling and bioaccumulation of $\mathrm{Hg}$, particularly the legacy $\mathrm{Hg}$ that has been stored in the system. Based on the insights from the $\mathrm{Hg}$ cycling in the Arctic Ocean, we postulate that $\mathrm{Hg}$ bioaccumulation in TGR is increasingly controlled by damming-induced changes in the internal processes, and that emission control of $\mathrm{Hg}$ will not result in immediate recovery of the ecosystem. Instead, emission control is expected to be followed by long delays before ensuing reduction is seen in food-web $\mathrm{Hg}$ levels. This response lag makes it all the more urgent to reduce or halt further loading of $\mathrm{Hg}$ to the system.

Unlikely the Arctic Ocean where intensive studies have resulted in $\mathrm{Hg}$ time-series data for many species for the past three decades [6], our ability to project how $\mathrm{Hg}$ levels in TGR will change is extremely limited due to a genuine lack of reliable time series of $\mathrm{Hg}$ in any biotic or abiotic compartment of the reservoir. Given the major implications of a processes-driven $\mathrm{Hg}$ bioaccumulation on pollution prevention and remediation, there is a pressing need to start a long-term monitoring program that will systematically and holistically monitor how Hg levels in the abiotic and biotic compartments are changing. Targeted and hypothesis-driven research should also be carried out, with a focus on key processes involved in the $\mathrm{Hg}$ biogeochemical cycles (Table 3). To rectify the lack of data before the impoundment, efforts should be taken to reconstruct the chronology from sediment cores or other abiotic and biotic archives. It is only through such careful and coordinated monitoring and research that the risk of another major $\mathrm{Hg}$ problem can be reduced. This is especially important given the large human population inhabiting the reservoir region and downstream. If there is any lesson that can be learnt from the $\mathrm{Hg}$ problem in the Arctic Ocean, that is, when an aquatic ecosystem is polluted by $\mathrm{Hg}$, it will take a very long time to recover, long after the emission sources are placed under control.

This work was supported by the Natural Science and Engineering Council (NSERC) of Canada (F.W.) and the National High Technology Research and Development Program of China (2012AA101405). We thank Dr. Yong Cai for his kind invitation to write this review.

1 Clarkson T W. The three modern faces of mercury. Environ Health Persp, 2002, 110: 11-23

2 Waldron H A. Did the mad hatter have mercury poisoning? Brit Med J, 1983, 287: 1961

3 Harada M. Minamata disease: Methylmercury poisoning in Japan caused by environmental pollution. Crit Rev Toxicol, 1995, 25: 1-24

4 Bakir F, Damluji S F, Amin-Zaki L, et al. Methylmercury poisoning in Iraq. Science, 1973, 181: 230-241

5 Grandjean P, Landrigan P J. Developmental neurotoxicity of industrial chemicals. Lancet, 2006, 368: 2167-2178

6 AMAP, Oslo, Norway: Arctic Monitoring and Assessment Program, 2011

7 Streets D G, Zhang Q, Wu Y. Projections of global mercury emissions in 2050. Environ Sci Technol, 2009, 43: 2983-2988

8 Wang F, Macdonald R W, Stern G A, et al. When noise becomes the signal: Chemical contamination of aquatic ecosystems under a changing climate. Mar Pollut Bull, 2010, 60: 1633-1635

9 Andersson M E, Gardfeldt K, Wangberg I, et al. Determination of Henry's law constant for elemental mercury. Chemosphere, 2008, 73: 587-592

10 Wania F, Mackay D. Tracking the distribution of persistent organic pollutants. Environ Sci Technol, 1996, 30: 390A-396A

11 Goodsite M E, Plane J M C, Skov H. A theoretical study of the oxidation of $\mathrm{Hg}^{0}$ to $\mathrm{HgBr}_{2}$ in the troposphere. Environm Sci Technol, 2004, 38: 1772-1776

12 Simpson W R, von Glasow R, Riedel K, et al. Halogens and their role in polar boundary-layer ozone depletion. Atmos Chem Phys, 2007, 7: $4375-4418$

13 Schroeder W H, Anlauf K G, Barrie L A, et al. Arctic springtime depletion of mercury. Nature, 1998, 394: 331-332

14 Martell A E, Hancock R D. Metal Complexes in Aqueous Solutions. New York: Springer, 1995

15 Zhang J, Wang F, House J D, et al. Thiols in wetland interstitial waters and their role in mercury and methylmercury speciation. Limnol Oceanogr, 2004, 49: 2276-2286

16 Lemes M, Wang F. Methylmercury speciation in fish muscle by HPLC-ICP-MS following enzymatic hydrolysis. J Anal At Spectrom, 2009, 24: 663-668

17 Aschner M, Aschner J L. Mercury neurotoxicity: Mechanisms of blood-brain barrier transport. Neurosci Biobehav Rev, 1990, 14: 169-176

18 Compeau G C, Bartha R. Sulfate-reducing bacteria: Principal methylators of mercury in anoxic estuarine sediment. Appl Environ Microbiol, 1985, 50: 498-502

19 Kerin E J, Gilmour C C, Roden E, et al. Mercury methylation by dissimilatory iron-reducing bacteria. Appl Environ Microbiol, 2006, 72: 7919-7921

20 Hamelin S, Amyot M, Barkay T, et al. Methanogens: Principal methylators of mercury in lake periphyton. Environ Sci Technol, 2011, 45: 7693-7700

21 Larose C, Dommergue A, De Angelis M, et al. Springtime changes in snow chemistry lead to new insights into mercury methylation in the 
arctic. Geochim Cosmochim Acta, 2010, 74: 6263-6275

22 Douglas T A, Loseto L, Macdonald R W, et al. The fate of mercury in Arctic terrestrial and aquatic ecosystems. A review. Environ Chem, 2012 (in press)

23 Sunderland E M, Mason R P. Human impacts on open ocean mercury concentrations. Global Biogeochem Cycles, 2007, 21: doi:10.1029/ 2006GB002876

24 Outridge P M, Macdonald R W, Wang F, et al. A mass balance inventory of mercury in the Arctic ocean. Environ Chem, 2008, 5: 89-111

25 Macdonald R W, Loseto L L. Are arctic ocean ecosystems exceptionally vulnerable to global emissions of mercury? A call for emphasised research on methylation and the consequences of climate change. Environ Chem, 2010, 10: 133-138

26 Loseto L L, Stern G A, Deibel D, et al. Linking mercury exposure to habitat and feeding behaviour in Beaufort Sea beluga whales. J Mar Systems, 2008, 74: 1012-1024

27 Feng X, Qiu G. Mercury pollution in Guizhou, southwestern ChinaAn overview. Sci Total Environ, 2008, 400: 227-237

28 Ye C, Li S, Zhang Y, et al. Assessing heavy metal pollution in the water level fluctuation zone of China's Three Gorges Reservoir using geochemical and soil microbial approaches. Environ Monit Assess, 2012, doi: 10.1007/s10661-10012-12547-10667

29 Tian H, Wang Y, Xue Z, et al. Atmospheric emissions estimation of $\mathrm{Hg}$, As, and Se from coal-fired power plants in China, 2007. Sci Total Environ, 2011, 409: 3078-3081

30 Jin L, Xu X, Liu J. Mercury distribution in coal, soil and sediment of the Three-gorge reservoir. Chongqing Environ Sci, 1997, 19: 33-35

31 Feng X B, Sommar J, Lindqvist O, et al. Occurrence, emissions and deposition of mercury during coal combustion in the province Guizhou, China. Water Air Soil Pollut, 2002, 139: 311-324

32 Yang Y, Chen H, Wang D. Spatial and temporal distribution of gaseous elemental mercury in Chongqing, China. Environ Monitor Assess, 2009, 156: 479-489

33 Fu X, Feng X, Wang S, et al. Temporal and spatial distributions of total gaseous mercury concentrations in ambient air in a mountainous area in southwestern China: Implications for industrial and domestic mercury emissions in remote areas in China. Sci Total Environ, 2009, 407: 2306-2314

34 Fu X W, Feng X, Dong Z Q, et al. Atmospheric gaseous elemental mercury (GEM) concentrations and mercury depositions at a highaltitude mountain peak in south China. Atmos Chem Phys, 2010, 10: 2425-2437

35 Wu W, Xie D T, Liu H B. Spatial variability of soil heavy metals in the Three Gorges area: Multivariate and geostatistical analyses.
Environ Monit Assess, 2009, 157: 63-71

36 National Environmental Protection Agency (NEPA). Background Values of Elements in Soils of China. Beijing: China Environmental Science Press, 1990

37 Hu C W, Li Q, Wang R F, et al. Study on toxic heavy metals (As, Hg, $\mathrm{Pb}$, and $\mathrm{Cr}$ ) in water bodies of the Three Gorges Reservoir after the impoundment. In: Proceedings of the Proceedings in the 3rd National Conference of Environmental Chemistry, November 4-7, 2005, Xiamen, China, 2005

38 Ran X B, Yu Z G, Chen H T, et al. Distribution of dissolved inorganic mercury in the lower part of the Three Gorges Reservoir. Environ Sci, 2008, 29: 1775-1779

39 Zhou X, Zheng J, Zhang S, et al. Heavy metals distribution of soils in water-level-fluctuating zone of the Three-Gorges Reservoir. Environ Monitor China, 2006, 22: 86-88

40 Zhang Y M, Liu H, Wei S Q, et al. Investigation and assessment of heavy metal pollution from various vertical heights in water flooding fluctuation zone of Three Gorges Reservoir areas. Chin Agri Sci Bull, 2011, 27: 317-322

41 Xu X, Qiu C, Deng G, et al. Chemical-ecological effects of mercury pollution in the Three Gorges Reservoir area. Acta Hydrobiol Sin, 1999, 23: 197-203

42 Jin L, Xu X. Methylmercury distribution in surface water and fish in the Three-Gorge Reservoir area. Resources Environ Yangtze Valley, 1997, 324-318

43 Zhang L, Zang X, Xu J, et al. Mercury bioaccumulation in fishes of Three Gorges Reservoir after impoundment. Bull Environ Contam Toxicol, 2007, 78: 262-264

44 Cai S, Ni Z, Li Y, et al. Metals in the tissues of two fish species from the rare and endemic fish nature reserve in the upper reaches of the Yangtze River, China. Bull Environ Contam Toxicol, 2012, doi: 10.1007/s00128-012-0564-4

$45 \mathrm{Yu} \mathrm{Y,} \mathrm{Wang} \mathrm{Y} \mathrm{C,} \mathrm{Gao} \mathrm{B,} \mathrm{et} \mathrm{al.} \mathrm{Assessment} \mathrm{on} \mathrm{pollution} \mathrm{risk} \mathrm{of}$ mercury in fishes of Three Gorges Reservoir after $175 \mathrm{~m}$ impoundment. Resources Environ Yangtze Valley, 2012, 21: 547551

46 Kelly C A, Rudd J W M, Bodaly R A, et al. Increases in fluxes of greenhouse gases and methyl mercury following flooding of an experimental reservoir. Environ Sci Technol, 1997, 31: 1334-1344

47 Liu B, Yan H, Wang C, et al. Insights into low fish mercury bioaccumulation in a mercury-contaminated reservoir, Guizhou, China. Environ Pollut, 2012, 160: 109-117

48 Feng X, Li P, Qiu G, et al. Human exposure to methylmercury through rice intake in mercury mining areas, Guizhou Province, China. Environ Sci Technol, 2008, 42: 326-332

Open Access This article is distributed under the terms of the Creative Commons Attribution License which permits any use, distribution, and reproduction in any medium, provided the original author(s) and source are credited. 